\title{
The Interface of Lexical Semantics and Conceptual Structure Deverbal and Denominal Nominalizations
}

\author{
Klaus von Heusinger, University of Konstanz \\ klaus.heusinger@uni-konstanz.de
}

\begin{abstract}
Nominalizations can refer to events, instances of events or participants in an event. The particular reference is determined by the lexical semantics of the base and the suffix, and by the conceptual structure of the base. The comparison between deverbal and denominal nominalization in -ata in Italian reveals that the conceptual structure plays a crucial role in determining the reference of a nominalization. Italian nominalizations of -ata are productively derived from verbal and nominal bases. Derivations from verbal bases refer to a single event denoted by the base. Derivations from a nominal base $N$ denote events or results corresponding to a limited number of patterns, such as a hit by $N$, a characteristic action of $N$, a period of $N$, a quantity that is contained in $N$, etc. The paper argues that the function of the suffix operates on the lexical meaning of the base, but the composition of the lexical meaning of the base with the lexical meaning of the suffix is restricted by the conceptual properties of the base.
\end{abstract}

\section{$1 \quad$ Introduction*}

Italian nominalizations with -ata can be derived from verbal or nominal bases. They form single individuated events that are expressed by their bases, as illustrated in (1). The nominalization telefonata is derived from the denominal telefonare, documented in 1918 for the first time (see Sabatini \& Coletti 1997). Derivations in - ata from a nominal base $\mathrm{N}$ denote single events or results according to certain patterns or "templates". They can denote single events of a hit by $N$, as in (2); events that are characteristic for $N$, as in (3); a period of $N$, as (4), a result in form of a capacity that is contained in $N$, as in (5); to name only four out of a longer list of productive patterns for -ata (see section 3.2 for a more comprehensive list):

(1) telefonata $(<$ telefonare "to call by telephone")

(2) ombrellata (< ombrello "umbrella" (1841))

(3) bambinata $(<$ bambino "child" (18 th cent.))

(4) giornata (< giorno "day" (13 th cent.))

(5) forcata $(<$ forca "fork" (15th cent.))

\author{
"telephone-call" (1918) \\ "event of hitting with an umbrella" \\ "event typical for a child" \\ "time of a day" \\ "forkful"
}

A single derivation in -ata can be assigned different meanings. For example, fermata can denote the event of stopping, the place of stopping or the time period of a stop, as in (6); and barcata may either refer to the load that can be carried by a boat or to a large quantity in general, as in (7). Even if these differences in meaning can be derived by general principles of meaning variation or meaning change, such as metonymy, figurative use, construals or coercion, the two meanings of forcata in (8) cannot be derived from each other. Rather, they must follow from two independent patterns, namely the ones illustrated in (2) and (5): (i) $a$ hit by $N$ and (ii) a capacity that is contained in $N$. Besides lexicalized forms, the suffix -ata very

\footnotetext{
* This article is the intermediate result of a project on Italian nominalization that was initiated by Christoph Schwarze. First of all I would like to thank him for long discussions and encouraging and constructive comments, and Ewald Lang and Ilse Zimmermann for editing this volume. I also like to thank Silvia Guidolin, Carmen Kelling, Judith Meinschäfer, Heike Necker, Vieri Samek-Lodovici, Marie-Therese Schepping, Niko Spak-Dolt and in particular Ilse Zimmermann for comments and helpful suggestions. I also profited by presenting the material at the workshop Nominalisierungen at the Universität Tuibingen in April 2001 and at the conference The Lexicon in Linguistic Theory at the University of Düsseldorf in August 2001. Special thanks for the organizers and the audience for comments and suggestions. An extended version of this paper with additional appendices appeared as von Heusinger (2002).
} 
productively forms new nominalizations from verbal as well as from nominal bases, as illustrated in (9) and (10):

(6) fermata (< fermare "to stop") (17 th cent.)

(7) barcata (< barca "boat") (18 $18^{\text {th }}$ cent.)

$$
\begin{gathered}
\text { forcata }(<\text { forca "fork" }) \\
\left(15^{\text {th }} \text { cent. }\right)
\end{gathered}
$$

deverbal acceptable new forms

(10) denominal acceptable new forms (i) "the event of stopping"

(ii) "the location where a stop is usually done"

(iii) "the time period of a stop"

(i) "boatload"

("quantity that can be carried by a boat")

(ii) "large quantity"

(i) "stroke with a fork"

(ii) "forkful"

(quantity that can be carried by a fork")

aggirata < aggirare "to revolve"

analizzata < analizzare "to analyze"

abitata< abito "habit, custom"

amantata< amante "lover"

While nominalizations from verbal bases generally denote an instance of an event described by the meaning of the base, derivations in -ata from nominal bases have much greater variety of denotations. They can follow one of the above mentioned patterns, but they are also free to denote another kind of pragmatically salient type of event. However, it seems that they always denote an instance of an event. I, therefore, assume that there is a common function or common lexical meaning of the suffix -ata, which can be described as forming a single event. Besides this core meaning, the conceptual structure of the base restricts the particular meaning of the derived nominalization.

The meaning of a non-lexicalized form not only depends on the lexical meaning of the suffix, but also on the pragmatic and contextual circumstances. While the pragmatic and contextual information is to be described for each utterance separately, this paper investigates the contribution of the suffix to the meaning of the derivation and its interaction with the conceptual information of the base. In particular, I address to following questions with respect to the suffix -ata:

- Is there a core lexical meaning of the suffix -ata for all different patterns?

- How can we describe the differences between the derivations from nominal bases?

- Which conceptual properties of the base determine the particular meaning of the derived nominalization?

The paper is organized as follows: In section 2, I discuss the historical origin of the suffix -ata in Italian, which is of Latin origin and can also be found in other Romance languages. In section 3, I present more descriptive data on the derivations in Italian and the different groups of derivations as well as the discussion of the form of the suffix. In section 4, I describe the conceptual information of the base in terms of selectional restrictions, and in section 5 , I present a compositional process in which the representations of the bases are combined with different patterns of the suffix. Sorted variables in the representation for the different patterns must match with the selectional restrictions of the base. Section 6 gives a short summary.

\section{The diachronic development}

\subsection{The suffix -ata in Romance languages}

The suffix -ata in Italian is a common suffix in Romance languages, such as in Italian, Occitan, Spanish, French, Catalan, etc., as illustrated in (11). Parallel derivations in these languages can undergo similar meaning shifts, as illustrated in the shift from the event- 
reading ("entering") to the result-reading ("entry") of it. entrata (13th cent.) and its equivalents in other Romance languages, as in (12):

it. andata "going, journey"
occ. arribada "arrival"
spa. buscada "search"
fr. echappée "escape"
it. entrata
fr. entrée
spa. entrada

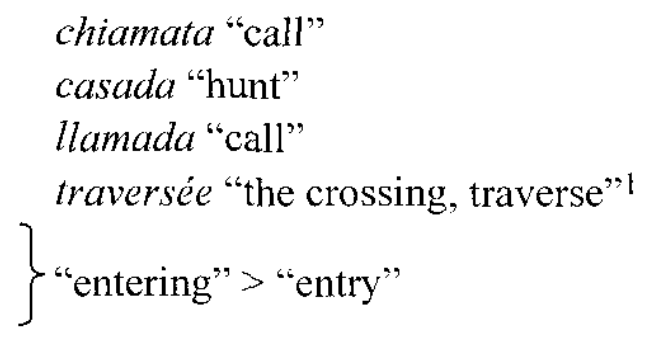

We find different patterns in nominalized forms from nominal bases: in (13a), the derivation refers to an amount that can be transported by the base, in (13b) the derivation refers to the time period of a day, while in (13c) the nominalization describes an event of a knife/swordstabbing:
a. fr. bouchée, it. boccata, spa. bocada
b. fr. journée, it. giornata, spa jornada
c. it. coltellata, spa. cuchillada, occ. coltelada, cat. espadada

\author{
"mouthful" \\ "day long" \\ "stab with a knife" \\ "stab with a sword"
}

\subsection{The Latin source of the suffix}

It is uncontroversial that the common Romance suffix goes back to a Latin form. Yet it is controversial how its form and its function developed. There are two main positions: MeyerLübke (1890) assumes that -ata has developed from the perfect participle by change of the semantic function. On the contrary, Collin (1918) argues that the suffix -ata has taken over the functional load from the Latin suffix -tus, while changing the form -tus into the form -ata by some intermediate steps.

\subsubsection{Meyer-Lübke: the participial source of -ata}

The formal identity of the suffix - ata with the feminine singular and the neuter plural of the perfect participle strongly suggest a close relation, even an identity. Therefore, Meyer-Lübke (1890), among others, suggested that the nominalizing suffix -ata was derived from the participle by syntactic ellipsis and some change of the semantic function of this form. Simplified, he argues that the adjectival use of participle collecta in collecta pecunia ("collected money") in (14) developed into a nominal use when the syntagma lacked its head noun, which had only little semantic content. ${ }^{2}$ In a second semantic shift, the function of the perfect participle was changed step by step. Generally, the perfect participle denotes a perfective or resultative state in the passive: collecta "that what was collected". First the form lost the passive aspect and then the perfective one, forming verbal nouns of the type "collecting", as in (15): ${ }^{3}$

\footnotetext{
1 In French, the original suffix - ata changed to - ée, as illustrated in (i):

(i) lat. armata $>$ armede $>$ armee $>$ nfr. armée $\mathrm{cf}$. it. armata, spa. armada

It was only in the $15^{\text {th }}$ and $16^{\text {th }}$ century that loan words from Italian and Occitan with the suffix -ade entered French again. Some native forms were replaced by the loan forms as in crevade (instead of an already established crevee), ambassade (ambassee), boutade (boutee), etc. (Collin 1918, 13f.).

2 Other head nouns with little or no semantic content are lat. res or causa ("thing", "cause"). Compare also it. cosa"thing" (p.c. Ilse Zimmermann).

3 Meyer-Lübke (cited in Collin 1914, 456): "Ital. veduta bedeutet also zuerst 'das Gesehene', dann durch Zeitverschiebung: 'das, was jederzeit gesehen wird', und man erhält anstatt des Begriffes der vollendeten Handlung den Begriff des Präsens. Zuletzt, in dem 'der eigentlich passivische, objektive Sinn' verloren geht und durch einen subjektiven, aktivischen ersetzt wird, bedeutet es nicht nur 'die Ansicht', d.h. was gesehen wird, sondern auch das Gesicht, d.h. zunächst die Art, wie man sieht, und schließlich die Thätigkeit des Sehens."
} 
(14) Ellipsis of the head noun

lat. collecta pecunia $>$ collecta $\emptyset>$ collecta

"the collected money" > "the collected (one)" > "the collected"

(15) Loss of passive and perfective marking

lat. collecta "the collected" > "collecting"

\subsubsection{Collin: the transformation of -tus into -ata}

Collin (1918) criticizes the participle approach as too complicated in the shift of meaning described above. He argues that the suffix -ata fills exactly the functional load of the old Latin suffix -tus. Thus, he concludes that -ata replaces -tus in its function by some intermediate steps of formal changes that are well motivated. Originally, Latin had two suffixes to form event nominals from verbal bases: the suffix - $(t)$ io formed verbal nouns with feminine gender, and $-t u s$, -sus which formed verbal nouns that were masculine in the $4^{\text {th }}$ declension. In earlier times there was a semantic difference between the two forms: while derivations of - $(t)$ io primarily denoted events, those of -tus tended to refer to results. ${ }^{4}$ However, in later times both derivations were used in the same way, thus producing parallel forms, as illustrated in (16). Collin assumes three steps of changing the form of -tus to -ata while keeping the semantic function. In the first step, the gender of the -tus forms was reanalyzed as neuter. Most nouns of the $4^{\text {th }}$ declension used to be masculine (thus ending in $-t u s$ ), with a small minority being neuter (ending in -tum). However, the similarity of the neuter forms of the $4^{\text {th }}$ declension with the neuter form of the $2^{\text {nd }}$ declension (cf. abortum) motivated a reanalysis of the original masculine forms towards neuter form. This reanalysis is also supported by the same form in the accusative singular for masculine and neuter. An additional motivation was the neutral singular of the perfect participle and the supinum:

abortio - abortus/abortum
accessio - accessus/accessum
cantio - cantus/cantum

"miscarriage"

"approaching, approach"

"singing, song"

(17) Shift of the gender and declension class

abortio [fem.] - abortus [masc., $4^{\text {th }}$ decl.] / abortum [neutr., $4^{\text {th }} \mathrm{decl} . \Rightarrow 2^{\text {nd }} \mathrm{decl}$.]

A second step is constituted by the common usage of the neuter plural instead of the singular, but with a collective or singular meaning. In a third step it is assumed that the neuter plural (with its singular meaning) is reanalyzed as a feminine singular of the first declension yielding the suffix -ata as feminine singular for forming event nominals, like the older forms of -tio and -tus, -sus. (Collin 1914, 1918). ${ }^{5}$

(18) Shift of grammatical number and reanalysis as feminine singular

lat. promissum $>$ promissa $>$ fr. la promesse

lat. debitum $>$ debita $>$ fr. la dette, span. la deuda

"promise"

lat. responsum $>$ responsa $>$ fr. la résponse

"debts"

"response"

\footnotetext{
${ }^{4}$ Derivations of $-(t)$ io outnumbered those by $-t u s$ by 5 to 1 in classical texts. This was partly because $-(t)$ io was the first choice for forming loan-translations from Greek in academic writing. Ruh $(1956,83)$ notes that the Greek words eulogia, epistrophe, empneusis, sympatheia were translated into Latin benedictio, conversio. inspiratio, compassio. Cicero complained about the large number of new forms in Latin, even though he himself contributed a large list of new loan-translation (cf. Lindquist 1936, 40). Collin (1918) notes that -tus was quite common in vulgar speech, as it can be seen from inscriptions.

5 Appel (1883, 42; cited in Collin 1918, 47): "Eodem modo, quo illa collectiva, alia neutra, cum pluraliter saepe usurparentur, in femina ideo conversa sunt, quod, quae proprie ex multis partibus constabant, in unam notionem coaluerunt. Ad hoc genus pertinent: dicta, promissa, responsa."
} 


\subsection{The origin of denominal forms of -ata}

The suffix -ata is productively used for forming event nominals from verbal bases from the very beginning of the Romance languages. It forms event nouns that denote one instance of the verbal action: "la fonction primitive de suffixe en roman a dû être d'exprimer l'action verbale d'une façon absolue: de former des nomina actionis" (Collin 1918, 125).

This pattern is very productive, and it can be formed from a great variety of verbal bases. ${ }^{6}$ Thus the verb camminare allows a nominalized form camminata, which then can be combined with a light verb meaning more or less what the base verb means. The form entrata from the verb entrare "to enter" has an event meaning, but also shows a more resultative reading ("entry"), as illustrated in (20):

(19)

(20)

camminata

fare una camminata

entrata ( $13^{\text {th }}$ cent.)

ha fatto un'entrata trionfale

l'entrata dell'albergo

$$
\begin{aligned}
& \text { "walk" } \\
& \text { "to go for a walk" } \\
& \text { "entry, entrance" } \\
& \text { "He entered with triumph" } \\
& \text { "the entrance to the hotel" }
\end{aligned}
$$

Besides this very productive pattern, an additional derivational pattern came into existence: the suffix - ata started to form nominalizations from nominal bases. This derivation developed by reanalysis of forms that either might have been derived from a denominal verb or directly from the nominal base of that verb, as in (21) and (23). In the next step, it was possible to derive directly from a nominal base, as in (22) or (24), where the same pattern is used: a hit with $N$ and the amount of $Y$ transported by $N^{7}$

$$
\begin{aligned}
& \text { it. martellata (14 } 14^{\text {th }} \text { cent.) "hammerblow" } \\
& <\text { martellare "to hammer" (< martello "hammer" (14th cent.)) } \\
& <\text { martello "hammer" }
\end{aligned}
$$

$$
\begin{aligned}
& \text { it. ombrellata (19 } 9^{\text {th }} \text { cent.) }<\text { ombrello "umbrella" } \\
& \text { *ombrellare } \\
& <\text { beccare "to peck" (< becco "beak" (14th cent.)) or } \\
& <\text { becco "beak" }
\end{aligned}
$$$$
\text { it. beccata (14th cent.) (i) "peck", (ii) "beakfull" }
$$

Additional patterns for the suffix -ata developed: a space of time, as in (25), an iteration of an architectonic detail, as in (26), a meal based on the referent of the nominal base, as in (27), and an action typical for that group of persons described by the nominal base, as in (28):

(25) it. giornata (13 th cent.) "daytime" < giorno "day"

(26) it. arcata (14th cent.) "arcade" < arco "arc"

(27) it. cipollata (15 th cent.) "meal prepared from onions" < cipolla "onion"

(28) it. ragazzata (16 th cent.) "childish action" < ragazzo "child"

\footnotetext{
${ }^{6}$ Certain verbs do not allow nominalizations of -ata. See Mayo et al. $(1995,912)$.

7 This development can also be stated for other Romance languages, such as French in (i) and (ii) (Collin 1918):

(i) fr. montée "ascending slope" < (i) ofr. monter or < (ii) ofr. mont

(ii) ofr. buce (ca 1120)> buchiee > nfr. bouchée "mouthful, bite" ofr. puing (ca 1180) > poignee > nfr. poignée "fist-ful"
} 
The deverbal derivation with -ata shows a quite coherent function: it forms nominalized derivations that denote "one instance of the event described by the verbal base". However, the denominal use of -ata exhibits a large variety of functions, as illustrated in (21)-(28) (see also section 3.2). It is not obvious that there is one basic function. The discussion in the literature, rather assumes that the denominal nominalization suffix -ata shows the same variety of functions as the derivation of denominal verbs. Collin $(1918,134)$ summarizes: "Pour moi, je crois plutôt que la grande variété de sens de netre suffixe s'explique par le rôle varié joué par le radical dans les verbes dénominatifs qui ont donné naissance à la formation analogique." In connection with denominative verbs, Collin $(1918,135)$ quotes Behaghel $(1900,1)$ : "Sie [= denominative verbs] dienen im allgemeinen zur Bezeichnung der Handlung, des Vorgangs, der bei Erwähnung des vom Hauptwort bezeichneten Begriffs am leichtesten ins Bewusstsein eintritt." and Bladin $(1911,57)$ : "Every action can be designated by a verb derived from the very noun, the idea of which most easily enters the mind of the person wanting to state the fact."

It is interesting to note, that Clark \& Clark $(1979,787,(23))$ formulate very similar conditions for forming denominal verbs (their "INNOVATIVES"):

(29) The Innovative Denominal Verb CONVEnTION

In using an innovative denominal verb sincerely, the speaker means to denote

(a) the kind of situation

(b) that he has good reason to believe

(c) that on this occasion the listener can readily compute

(d) uniquely

(e) on the basis of their mutual knowledge

(f) in such a way that the parent noun denotes one role in the situation, and the remaining surface arguments of the denominal verb denote other roles in the situation.

\section{Derivations of - ata in Italian}

\subsection{Productivity}

The Italian suffix -ata forms substantives in the feminine (sg.: $-a$, pl.: $-e$ ) which denote a single or individualized event (nomen vicis) or certain types of resultatives. The derivations are easily set into the plural. The suffix is very productive both from verbal as well as nominal bases. There are lexicalized forms and spontaneous forms, which are either acceptable or not. ${ }^{8}$ It seems that the main reason that ata-derivations from verbal bases are not acceptable due to lexical blocking.

(30) Deverbal nominalizations of -ata ( $=\mathrm{V}$-nominalizations)

i. lexicalized forms

$$
\begin{aligned}
& \text { abbassata "reduction" }(1913)<\text { abbassare "to lower" } \\
& \text { allargata "widening" }\left(18^{\text {th }} \text { cent. }\right)<\text { allargare "to widen" }
\end{aligned}
$$

ii. acceptable new forms

$$
\begin{aligned}
& \text { aggirata }<\text { aggirare "to revolve" } \\
& \text { analizzata }<\text { analizzare "to analyse" }
\end{aligned}
$$

iii. non-acceptable forms

*abbandonata $<$ abbandonare "to abandon"

8 Examples from Vieri Samek-Ludovici (1997), who extracted a list from the Lessico di frequenca dell italiano
parlato (De Mauro, Mancini, Vedovelli, Voghera 1993). The judgements are his own (and not uncontroversial). 


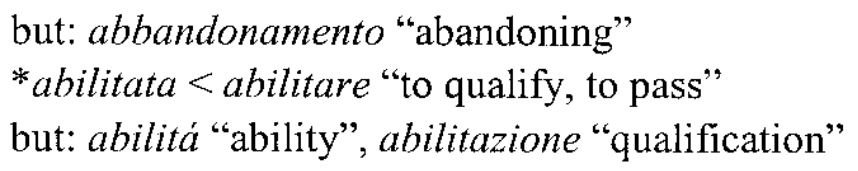

There are several suffixes that can derive nominalizations from verbal bases, as illustrated in (31).

(31) Possible nominalizations from verbal bases (Scalise 1986, 174)

\begin{tabular}{|l|c|c|c|c|c|c|c|}
\hline & $a$ & ata & enza & zione & ura & aggio & mento \\
\hline revoca(re) & + & - & - & - & - & - & - \\
\hline mangia(re) & - & + & - & - & - & - & - \\
\hline preferi(re) & - & - & + & - & - & - & - \\
\hline amministra(re) & - & - & - & + & - & - & - \\
\hline arde(re)/arso & - & - & - & - & + & - & - \\
\hline boicotta(re) & - & - & - & - & - & + & - \\
\hline suggeri(re) & - & - & - & - & - & - & + \\
\hline
\end{tabular}

There are selectional restrictions on the derivations from verbal bases: static verbs, modal verbs, aspectual verbs, and certain types of "psychological" verbs cannot form ata-nominalizations (Mayo et al. 1995, 912).

$$
\begin{aligned}
& \text { *avuta "act of having" } \\
& \text { *cominciata "act of starting" } \\
& \text { *rallegrata "act of cheering up" }
\end{aligned}
$$

$$
\begin{aligned}
& \text { *dovuta "act of needing" } \\
& \text { *sentita "act of perceiving" } \\
& \text { but: pensata "act of thinking" }
\end{aligned}
$$

The restriction for deriving nominalizations from nominal bases seems to be different. The pattern for denominal nominalizations are more restricted than for deverbal nominalizations. So it seems that blocking is less active here than lexical restrictions (see section 5):

(33) Denominal nominalization of -ata (=N-nominalizations)

i. lexicalized forms

$$
\begin{aligned}
& \text { bracciata i. "armful", } \\
& \text { ii. "armstroke" (14th cent.) } \\
& <\text { braccio "arm" } \\
& \text { barcata i. "boatload", "large quantity" (18 th cent.) } \\
& <\text { barca "boat" } \\
& \text { ii. acceptable new forms abitata < abito "habit, custom, tendency" } \\
& \text { amantata < amante "lover" } \\
& \text { *aeroportata < aeroporta "airport" }
\end{aligned}
$$$$
\text { iii. non-acceptable forms *accademiata < academia "academy" }
$$

\subsection{The functions of -ata in Italian}

As already noted, derivations in -ata exhibit different types of meaning. Deverbal nominalizations generally denote an individualized event, as in (34). This pattern is quite productive, and the derivation may shift its meaning to a more resultative meaning as in fermata. Denominal derivations can take different patterns, as listed in (35)-(41) (cf. MeyerLübke 1890, Collin 1918, Scalise 1986, Schwarze 1988, Samek-Lodovici 1997, Ippolito 1999 among others). Some irregular derivations are discussed in section 3.3 . 
tandata, data, guardata, chiamata, entrata, cambiata, fermata, intesa, caduta, giocata, dormita, girata, aggiunta, levata, attaccata, controllata, firmata, lavata, durata, difesa, battuta, curata, corsa, fregata, derivata, coperta, figliata, bloccata, avviata, fumata, arrabbiata, camminata, adoperata, bevuta, chiarita, aggiornata, faticata, approfondita, condotta, cancellata, ...

(35) N-ata: event of hitting with $\mathrm{N}$ or hitting with $\mathrm{N}$

librata, giornalata, linguata, frontata, lettata, bancata, codiciata, bigliettata, corpata, fotata, cavallata, fogliata, cassettata, gambata, corniciata, lenzuolata, cassata, aereata, fiancata, cassettata, discata, bibliotecata, cartellata, finestrata, camiciata, anellata, bicchierata, fedata, ballata, ditata, bottigliata, cartolinata, autata, ...

(36) N-ata: event or action typically performed by $\mathrm{N}$ or act as $N$

ragazzata, bambinata, Clintonata, Fellinata, gattata, animalata, agentata, caprata, adultata, amicata, amministratorata, arabata, artistata, autorata, bestiata

(37) N-ata: quantity that can be carried by/in $N$

aulata, armadiata, barcata, boccata, bracciata, borsata, bustata, camerata, camionata, cartellata

(38) N-ata: period of time of $N$ :

giornata, annata, aprilata, dicembrata, gennaiata

(39) N-ata: meal prepared on the base of $N$ : fungata, carciofata, cipollata

(40) N-ata: object constructed by the repetition of $N$ : arcata, colonnata, facciata

(41) N-ata: weather verb: acquata, albata

Scalise $(1986,209)$ presents the categorization (42) of the different patterns. He summarizes his observations: "Quando -ata si aggiunge a nomi presenta una grande varietà di parafrasi (6i-vi), ma quando si aggiunge a verbi ha solamente una parafrasi (6viii), che è diversa da quelle date per i nomi."

(42) Scalise $(1986,209)$

\begin{tabular}{|c|c|c|c|c|}
\hline (i) & piede & $\rightarrow$ & pedata & "colpo di N" \\
\hline (ii) & cucchiaio & $\rightarrow$ & cucchiaiata & "quantità contenuta in N" \\
\hline (iii) & cretino & $\rightarrow$ & cretinata & "atto da N" \\
\hline (iv) & cancello & $\rightarrow$ & cancellata & “insieme di N" \\
\hline (v) & anno & $\rightarrow$ & annata & "successione di N" \\
\hline (i) & arancio & $\rightarrow$ & aranciata & "prodotto di N" \\
\hline (ii) & guardare & $\rightarrow$ & guardata & "singolo atto di N" \\
\hline
\end{tabular}

\subsection{The form of the suffix}

It is controversial if we have only one suffix for verbal and nominal bases, or if there are two suffixes, $-a$ for the verbal bases, and -ata for nominal bases. The latter position is taken by Scalise. If we assume that there is only one suffix, it is not so clear what its form looks like: $a t a,-t a$ or only $-a$. I first present the analysis for the derivations from the verb and then I discuss the approaches to derivations from nominal bases. 


\subsubsection{Analysis of V-nominalizations ${ }^{9}$}

$\mathrm{V}$-nominalizations are formed by suffixing a feminine $-a$ suffix to the past participle of the verb, yielding a feminine nominal form, as illustrated in (43): ${ }^{10}$

(43) Derivation of V-nominalizations
1. Base (+theme vowel) V
2. Past participle
$\mathrm{V}$
$[[\mathrm{V}]+\mathrm{PP}]_{\text {pastpart }}$
$\left[[[\mathrm{V}]+\mathrm{PP}]_{\text {pastpart }}+\mathrm{a}\right]_{\mathrm{N}}$
ferm- $a$
fermat-
3. Deverbal nominalization $\left[[[\mathrm{V}]+\mathrm{PP}]_{\text {pastpart }}+\mathrm{a}\right]_{\mathrm{N}} \quad$ fermata

The analysis is supported by the fact that V-nominalizations of this type follow the form of the participles in the different conjugation classes of Italian, as illustrated in (44), and also the irregular forms, as illustrated in (45) (for more discussion see Samek-Lodovici 1997, Ippolito 1999):

(44)

$\begin{array}{cll}\text { Past participle and nominalization in "-ata" } & \\ \text { conj. } & \text { verbal base } & \text { past participle } \\ \text {-are } & \text { sal-a-re "to salt" } & \text { sal-at-o } \\ \text {-ere } & \text { batt-e-re "to beat" } & \text { batt-ut-o } \\ \text {-ire } & \text { dorm-i-re "to sleep" } & \text { dorm-it-o }\end{array}$

nominalization
sal-at $-a$
batt - ut $-a$
dorm-it-a

(45) Irregular past participle and nominalization in "-ata"

$\begin{array}{lll}\text { verbal base } & \text { past participle } & \text { nominalization } \\ \text { compar-i-re "to appear" } & \text { compar-s-o } & \text { compar-s-a } \\ \text { corr-e-re "to run" } & \text { cor }-s-o & \text { cor }-s-a \\ \text { prend-e-re "to take" } & \text { pre- } s-o & \text { pre- } s-a\end{array}$

I am not totally convinced by this argument since the irregular forms go back to the Latin forms, and they might probably be determined by phonological rules that apply to verbal as well as nominal forms.

\subsubsection{Analysis of $\mathrm{N}$-nominalizations}

There are two options for the analysis of $\mathrm{N}$-nominalizations in -ata: the first option is taken by Scalise (1986), who assumes that the V-nominalizations are formed by a suffix $-a$, while the $\mathrm{N}$-nominalization are formed by a different suffix -ata. However, this analysis would separate the nominalizations into two subtypes with two different derivational processes. ${ }^{11}$ Therefore, Samek-Lodovici (1997), Ippolito (1999), among others, have suggested that Nnominalizations are derived by the same suffix $-a$ as the $\mathrm{V}$-nominalization. They assume an additional derivation from the nominal base to a (virtual) verbal base, according to the following schema (46) and the examples (21)-(24), repeated in (47): for the derivation of martellata, we assume a nominal base martell(-o) ("hammer"), which is then transformed into a verbal base martell $V$. This is also documented by the verb martellare "to hammer". Then the perfect participle is formed: martellat, the $\mathrm{N}$-nominalization is formed, and finally the feminine agreement marker $-a$ is attached to it. The same derivation holds for beccata. We assume the same steps for the derivation bocc-ata, even though the intermediate verbal forms are not documented nor do they seem to be accepted forms of Italian.

\footnotetext{
9 This section is based on Samek-Lodovici (1997, 3-4).

10 Alternatively, the suffix $-a$ could be simply analyzed as the inflexion or agreement feature for [+fem], rather than as derivational suffix (p.c. Christoph Schwarze). This would mean that the derivation from the participle to the nominalization is not represented by an overt suffix.

11 Samek-Lodovici $(1997,22)$ : "Italian a-nominalizations constitute one of the strongest challenge to Aronoff's (1979) Unitary Base Hypothesis, because they productively allow for both verbal and nominal bases. This work argues that contrary to appearance, every morphological step within the derivation of a-nominalization satisfies Aronoff's Unitary Base Hypothesis."
} 
1. Base

2. Derivation to $\mathrm{V}$ (+ theme vowel)

3. Past participle

4. Deverbal nominalization
$\mathrm{N}$

$[\mathrm{N}] \mathrm{V}$

$\left[[\mathrm{N}]_{\mathrm{V}}+\mathrm{PP}\right]_{\text {pastpart }}$

$\left[\left[[\mathrm{N}]_{\mathrm{V}}+\mathrm{PP}\right]_{\text {pastpart }}+\mathrm{a}\right]_{\mathrm{N}}$

(47)
1. N
martell $_{N^{-}}$"hammer"
$\operatorname{becc}_{N^{-}}$"beak"
bocc $_{N^{-}}$"mouth"
2. V martell $V^{-}$(martellare)
becc $_{V^{-}}$(beccare)
boccV- (*boccare)
3. Vpp martell-at-(martellato)
becc-at- (beccato)
4. Nom
martell-at- $a_{N}$
becc-at- $a_{N}$
"hammerblow"
(i) "peck"
bocc-at $(*$ boccato $)$
bocc-at-a $N$
"mouthful"
(ii) "beakfull"

To sum up, there are different analyses of the nominalizations in -ata. I do not take a position here, rather I follow Mayo et al. $(1995,913)$ :

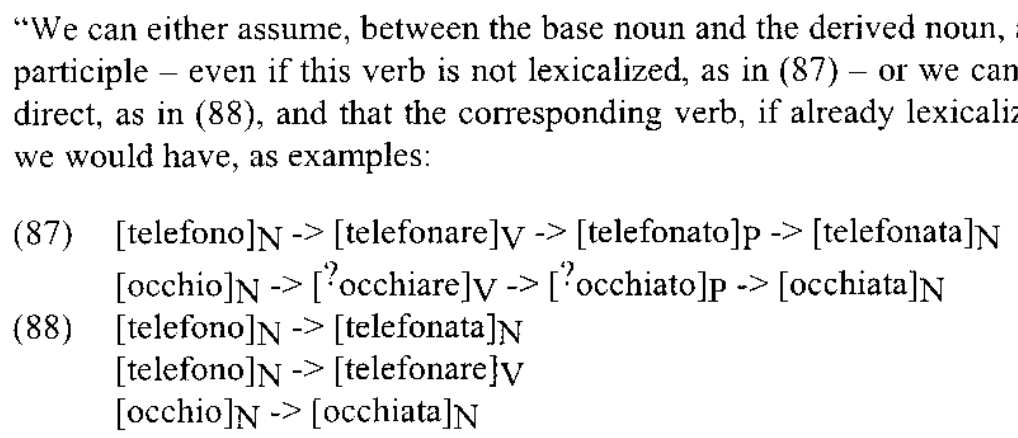

It is not necessary here to decide between the alternatives (they are indeed two parallel paths to the same goal in the case of telefonata). For the sake of simplicity we shall assume the more direct derivations shown in (88), using a single derivational operator that leads directly from a noun to an event."

Still, we have to account for the contribution of the suffix -ata to the meaning of the derivation. I investigate this contribution at the level of argument structure and different lexical representations.

\section{Conceptual patterns and selectional restrictions}

Nominalizations of -ata are quite productive: formed from verbal bases, they denote an instance of an event described by the verb. Formed from a nominal base, they show a great variety of meanings. This variety is comparable to the meaning variations of denominal verbs. However, lexicalized forms follow a closed set of patterns, as illustrated in section 3.2. This closed set of patterns also influences the production and the interpretation of spontaneous new forms, as it will be shown below.

The question is which factors may restrict or determine the pattern applied. In the following I concentrate on four patterns, the hit with $N$, act as $N$, capacity of $N$ to transport, and meal made of $N$. A simplified observation is that conceptual properties of the nominal base determine which of the potential pattern can be applied and which not. The conceptual properties, i.e. properties under which we perceive certain objects, are represented as semantic features of the lexical entries. We can now give a schematic representation of the different patterns, as in (48). E.g., the hit-pattern denotes an event that consists of the structure: hit $(e, x, y, N)$, where the base $N$ is in the Instrument slot of that predicate (or event). The object we can hit with must be solid and not to large (otherwise we were not able to hit with it), therefore the base must have the semantic features [+solid] and [+small]. Similar observations lead to the characterization given in (48):

(48) The Structures of the patterns to form nominalizations with -ata 


\begin{tabular}{|l|l|l|l|l|}
\hline Pattern & predicate structure & $\begin{array}{l}\text { semantic } \\
\text { role of N }\end{array}$ & $\begin{array}{l}\text { semantic } \\
\text { features of } \mathrm{N}\end{array}$ & $\begin{array}{l}\text { referential } \\
\text { argument }\end{array}$ \\
\hline hit with N & hit(e, $\mathrm{x}, \mathrm{y}$, with $\mathrm{N})$ & Instrument & $\begin{array}{l}\text { +solid, } \\
\text { +manageable }\end{array}$ & e (event) \\
\hline act as N & act(e, $\mathrm{x}$, as $\mathrm{N})$ & Agens & + human & e (event) \\
\hline $\begin{array}{l}\text { capacity of } \\
\mathrm{N}\end{array}$ & $\begin{array}{l}\text { transport(e, } \mathrm{x}, \mathrm{y}, \\
\text { with } \mathrm{N})\end{array}$ & $\begin{array}{l}\text { Instrument } \\
\text { (capacity) }\end{array}$ & $\begin{array}{l}\text {-human, } \\
\text { +capacity } 12\end{array}$ & $\begin{array}{l}\text { theme } \\
\text { (amount that } \\
\text { is carried) }\end{array}$ \\
\hline $\begin{array}{l}\text { meal made } \\
\text { with/of N }\end{array}$ & $\begin{array}{l}\text { prepare(e, } \mathrm{x}, \mathrm{y}, \\
\text { with/of N) }\end{array}$ & $\begin{array}{l}\text { Instrument } \\
\text { Base }\end{array}$ & +eatable & $\begin{array}{l}\text { y: result of } \\
\text { the event }\end{array}$ \\
\hline
\end{tabular}

It seems that we can assign to each pattern a characteristic set of semantic features. If this is correct, we should be able to predict from the semantic features of the base the potential pattern of an ata-nominalization. This is born out in (49), where I give the semantic features for libro, ragazzo, bocca, fungo, becco and barca, predicting the pattern of the nominalization. The prediction is confirmed by the lexicalized forms of these bases (see above section $3.2)$.

(49) Conceptual properties of nominal bases for lexicalized forms in -ata

\begin{tabular}{|c|c|c|c|c|c|c|}
\hline base & human & eatable & capacity & solid & $\begin{array}{c}\text { manage- } \\
\text { able }\end{array}$ & Type of -ata \\
\hline libro & - & - & - & + & + & hit \\
\hline ragazzo & + & - & - & - & - & act \\
\hline bocca & - & - & + & - & + & capacity \\
\hline fungo & $=$ & $\bar{f}$ & 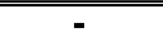 & $=$ & $\bar{T}$ & meal \\
\hline becco & - & - & + & + & + & cap., hit \\
\hline barca & - & - & + & + & - & capacity \\
\hline
\end{tabular}

In the next step I propose to make predictions for potential patterns for spontaneous forms (i.e. non-lexicalized forms). The base sedia "chair" has the semantic features +solid +small (or relative small or manageable). Therefore, one would expect that the form sediata denotes a "hit with a chair", as in (50):

(50) Conceptual properties of nominal bases for spontaneous forms in -ata

\begin{tabular}{|l|c|c|c|c|l|l|}
\hline base & human & eatable & capacity & solid & $\begin{array}{l}\text { manage- } \\
\text { able }\end{array}$ & Type of -ata \\
\hline sedia & - & - & - & + & + & hit \\
\hline
\end{tabular}

The result of an internet search has provided the following text (51), which confirms the predictions. This text is very informal and close to spontaneous speech.

(51) Road Dogg e Steve Blackman si affrontano per il titolo hardcore, azione molto violenta come sempre. DDT di Dogg ma Blackman reagisce con una sediata in testa che gli vale il pin vincente. X-Pac che commentava l'incontro con Jim Ross e Jerry Lawler, dice che lui e Road Dogg hanno discusso su chi sia il miglior wrestler singolo tra loro 2, e che dopo stasera, sfiderà Blackman a Smackdown per il titolo hardcore.

"(...) Dogg reacted to Blackman with a "sediata" on the head that was worth the victoryPIN...."

(Source: http://www.geocities.com/Colosseum/Track/5544/riw2407.html WWF Raw Is Review - By Erik Ganzerli, Edizione del 24.07.2000)

12 Cf. Collin $(1918,189)$ : “[...] le primitif est un instrument d'une certaine capacité." 
It is interesting to note that there is an irregular -ata form from the verb sedere, namly, seduta "sitting, meeting":

(52) seduta "sitting, meeting" from sedere "to be seated, to be sitting"

\section{$5 \quad$ Lexical representations}

I assume that the suffix -ata has the following functions:

(i) it changes the categorial properties of the base to [N, fem.]

(ii) it shifts the referential argument to the event argument (or some resultative one)

(iii) it characterizes the event as a single event or an instance of an event ${ }^{13}$

(iv) it requires additional restrictions which are determined by the conceptual structure of the base ${ }^{14}$

The common function of the suffix -ata is to refer to a single event of the type of the base. This is best seen in the case of a verbal base, generally described in (53). An event $e$ is called individualized (or "instance of P") if $e$ does not overlap with another event $e$ ' that is a P. This property will be represented by a predicate INDIV that is predicated of the event variable $e$. So we can have two instances of entering or two instances of (making a) telephone call, but they do not overlap. They are rather distinguishable, and therefore we can count them.

\section{V-ata: "single event of V" or "individualized event of V"}

In order to determine the lexical contribution of the suffix -ata to the derivation, we compare the lexical semantic representation of the verbal base with that one of the nominalized form. The intransitive verb entrare is assigned the lexical semantics in (54a): it describes events of the type that someone enters. The nominalized form entrata is assigned the semantics in (54b): it refers to individualized events of entering (I have suppressed other information such as the PP or the place that is entered). Under the assumption that the suffix -ata is applied to the verbal base by functional application, we yield the lexical semantics in (54c): the suffix takes a predicate and yields a nominalized form. (55) demonstrates the derivation for a transitive verb. The lexical representation of -ata has to take care of the transitive predicate. 15
a. entrare $\lambda \times \lambda \mathrm{e}[\mathrm{enter}(\mathrm{e}, \mathrm{x})]$
b. entrata
$\lambda \mathrm{e}[\mathrm{enter}(\mathrm{e}, \mathrm{x}) \& \operatorname{INDIV}(\mathrm{e})]$
c. -ata
$\lambda \mathrm{P} \lambda \mathrm{e}[\mathrm{P}(\mathrm{e}, \mathrm{x}) \& \operatorname{INDIV}(\mathrm{e})]$
a. lavare
$\lambda y \lambda x \lambda \operatorname{er} \operatorname{wash}(e, x, y)]$

13 Cf. already Collin $(1918,153)$ and quotations therein (e.g. Meyer-Lübke 1890)

14 Schwarze $(2001,15 \mathrm{ff}$ ) argues that at -nominalizations are rather underspecified in their meaning. They need additional information from the conceptual system: "Dove trova il parlante la risoluzione delle variabili create dall'operatore -ata? Le informazioni necessarie a questo scopo non fanno parte del lessico definito come componente della grammatica mentale, bensì del sistema concettuale."

15 In order to keep the representation as simple as possible, I have suppressed information about the nominal linking of arguments. The representation of the arguments that can be realized as genitive would be like (54') and $\left(55^{\prime}\right)$. However, in the remainder I will suppress them since they are not crucial to the argument here.

$\left(54^{\prime}\right)$ a.entrare $\quad \lambda \times \lambda \mathrm{e}[\mathrm{enter}(\mathrm{e}, \mathrm{x})]$

(54') b. entrata $\quad(\lambda \mathrm{x}) \lambda \mathrm{e}[\operatorname{enter}(\mathrm{e}, \mathrm{x}) \& \operatorname{INDIV}(\mathrm{e})] \quad\left(55^{\prime}\right) \mathrm{b}$. lavata

(54') c.-ata

$\lambda \mathrm{P}(\lambda \mathrm{x}) \lambda \mathrm{e}[\mathrm{P}(\mathrm{e}, \mathrm{x}) \& \operatorname{INDIV}(\mathrm{e})]$

$\left(55^{\prime}\right)$ c.-ata

$\lambda y \lambda x \lambda \mathrm{e}[\operatorname{wash}(\mathrm{e}, \mathrm{x}, \mathrm{y})]$

$(\lambda y) \lambda \mathrm{e}[\operatorname{wash}(e, x, y) \& \operatorname{INDIV}(e)]$

$\lambda \mathrm{P}(\lambda \mathrm{y}) \lambda \mathrm{e}[\mathrm{P}(\mathrm{e}, \mathrm{x}, \mathrm{y}) \& \operatorname{INDIV}(\mathrm{e})]$

A general form for the suffix is (i), where the predicate takes $n$ arguments (besides the event argument) Additionally, I assume that only the highest argument can be instantiated by a genitive.

(i) -ata $\lambda \mathrm{P}\left(\lambda \mathrm{x}_{\mathrm{n}}\right) \lambda \mathrm{e}\left[\mathrm{P}\left(\mathrm{e}, \mathrm{x}_{1}, \ldots \mathrm{x}_{\mathrm{n}}\right) \& \operatorname{INDIV}(\mathrm{e})\right]$ 


$$
\begin{array}{lll}
\text { b. } & \text { lavata } & \lambda \mathrm{e}[\operatorname{wash}(\mathrm{e}, \mathrm{x}, \mathrm{y}) \& \operatorname{IndiV}(\mathrm{e})] \\
\text { c. } & - \text { ata } & \lambda \mathrm{P} \lambda \mathrm{e}[\mathrm{P}(\mathrm{e}, \mathrm{x}, \mathrm{y}) \& \operatorname{Indiv}(\mathrm{e})]
\end{array}
$$

Before I give the representation for the denominal nominalization, I first discuss the derivation via a verbal form, as for martello $>$ martellare $>$ martellata (cf. (21) above). The nominal base is a simple predicate that takes one (referential) argument. The transitive verb martellare is represented in (56b) as the event $\mathrm{e}$ in which $\mathrm{x}$ does (to) $\mathrm{y}$ and in which a hammer is involved (here as general relation $\mathrm{R}$ ). Thus the verbalizing derivation must be described on the lines in (56c): it takes a noun $N$ and creates a transitive verb where the noun restricts the event by some relation $R .^{16}$

(56) a. martello $\lambda x[$ hammer(x)]

b. martellare $\lambda \mathrm{y} \lambda \mathrm{x} \lambda \mathrm{e}[\mathrm{DO}(\mathrm{e}, \mathrm{x}, \mathrm{y}) \& \exists \mathrm{z}[$ hammer(z) \& $\mathrm{R}(\mathrm{e}, \mathrm{z})]]$

c. $\quad[]_{\mathrm{N}} \rightarrow[\mathrm{N}]_{\mathrm{V}} \lambda \mathrm{N} \lambda \mathrm{y} \lambda \mathrm{x} \lambda \mathrm{e}[\mathrm{DO}(\mathrm{e}, \mathrm{x}, \mathrm{y}) \& \exists \mathrm{z}[\mathrm{N}(\mathrm{z}) \& \mathrm{R}(\mathrm{e}, \mathrm{z})]]$

In a second step we can derive the ata-form by applying its semantics (cf. $(55 \mathrm{c})=(57 \mathrm{~b})$ ) to the verbal base, yielding the semantics for the nominalization in $(57 \mathrm{c})$. Here the predicate $P$ comprises the more complex expression $\mathrm{DO}(\mathrm{e}, \mathrm{x}, \mathrm{y}) \& \exists \mathrm{z}$ [hammer(z) \& $\mathrm{R}(\mathrm{e}, \mathrm{z})]$. Alternatively, we can also derive the nominalized form directly from the nominal base, as in (58). The semantic representation of $-a t a_{l}$ is composed from the semantics of the verbalization (56c) and the semantics of deverbal -ata (57b):
a. martellare
$\lambda y \lambda x \lambda \mathrm{e}[\mathrm{DO}(\mathrm{e}, \mathrm{x}, \mathrm{y}) \& \exists \mathrm{z}[\mathrm{hammer}(\mathrm{z}) \& \mathrm{R}(\mathrm{e}, \mathrm{z})]]$
b. -ata
$\lambda \mathrm{P} \lambda \mathrm{e}[\mathrm{P}(\mathrm{e}, \mathrm{x}, \mathrm{y}) \& \operatorname{INDIV}(\mathrm{e})]$
c. martellata
$\lambda \mathrm{e}[\mathrm{DO}(\mathrm{e}, \mathrm{x}, \mathrm{y}) \& \exists \mathrm{z}[\mathrm{hammer}(\mathrm{z}) \& \mathrm{R}(\mathrm{e}, \mathrm{z})] \& \operatorname{IndIV}(\mathrm{e})]$
a. martello
$\lambda \mathrm{x}[$ hammer(x)]
b. -atal
c. martellata

$$
\begin{aligned}
& \lambda N \lambda e[\operatorname{Do}(e, x, y) \& \exists z[N(z) \& R(e, z)] \& \operatorname{Indiv}(e)] \\
& \lambda e[\operatorname{Do}(e, x, y) \& \exists z[\operatorname{hammer}(z) \& R(e, z)] \& \operatorname{InDIV}(e)]
\end{aligned}
$$

(58)

Note that the compositional semantics does not care if we account for the derivation in one or in two steps. The result is in both cases the same (or the other way around: we have determined the semantics of the derivational processes such that there is no semantic difference between these two ways of derivation.). So we can derive ombrellata from nominal ombrello either by one derivation, as in (59) or by an intermediate step (and a virtual verb), as in (60). At this point, semantics cannot decide for one way or other.

$$
\begin{aligned}
& \text { a. ombrello } \quad \lambda \mathrm{x}[\mathrm{umbrella}(\mathrm{x})] \\
& \text {-atal } \quad \lambda \mathrm{N} \lambda \mathrm{e}[\mathrm{Do}(\mathrm{e}, \mathrm{x}, \mathrm{y}) \& \exists \mathrm{z}[\mathrm{N}(\mathrm{z}) \& \mathrm{R}(\mathrm{e}, \mathrm{z})] \& \operatorname{INDIV}(\mathrm{e})] \\
& \text { c. ombrellata } \lambda \mathrm{e}[\operatorname{Do}(\mathrm{e}, \mathrm{x}, \mathrm{y}) \& \exists \mathrm{z}[\mathrm{umbrella}(\mathrm{z}) \& \mathrm{R}(\mathrm{e}, \mathrm{z})] \& \operatorname{INDIV}(\mathrm{e})] \\
& \text { (60) a. ombrello } \lambda x[u m b r e l l a(x)] \\
& +[]_{\mathrm{N}} \rightarrow[\mathrm{N}] \mathrm{V} \quad \lambda \mathrm{N} \lambda \mathrm{y} \lambda \mathrm{x} \lambda \mathrm{e}[\mathrm{DO}(\mathrm{e}, \mathrm{x}, \mathrm{y}) \& \exists \mathrm{z}[\mathrm{N}(\mathrm{z}) \& \mathrm{R}(\mathrm{e}, \mathrm{z})]] \\
& \text { b. *ombrellare } \quad \lambda \mathrm{y} \lambda \mathrm{x} \lambda \mathrm{e}[\mathrm{DO}(\mathrm{e}, \mathrm{x}, \mathrm{y}) \& \exists \mathrm{z}[\mathrm{umbrella}(\mathrm{z}) \& \mathrm{R}(\mathrm{e}, \mathrm{z})]] \\
& \text {-ata } \quad \lambda \mathrm{P} \lambda \mathrm{e}[\mathrm{P}(\mathrm{e}, \mathrm{x}, \mathrm{y}) \& \operatorname{INDIV}(\mathrm{e})] \\
& \text { c. ombrellata } \lambda \mathrm{e}[\operatorname{Do}(\mathrm{e}, \mathrm{x}, \mathrm{y}) \& \exists \mathrm{z}[\mathrm{umbrella}(\mathrm{z}) \& \mathrm{R}(\mathrm{e}, \mathrm{z})] \& \operatorname{INDIV}(\mathrm{e})]
\end{aligned}
$$

However, the problem with this analysis is that it is too general. Martellata means a hit with a hammer or a hammer blow, rather then an event related to a hammer, and ombrellata refers to a hit with an umbrella, rather than to an event with an umbrella. An event in which an umbrella is involved is typically one in which one uses the umbrella against rain, but not to hit someone. So the semantic representation must be more specified, as in (61a) and (61b),

${ }^{16}$ Ilse Zimmermann (p.c.) suggested this semantics to me. 
instead of $(57 \mathrm{c})$ and $(60 \mathrm{c})$. Here we have specified the predicate Do by the more specific Hit, and the relation $R$ by Instr.

(61) a. martellata $\lambda \mathrm{e}[\mathbf{H i t}(\mathrm{e}, \mathrm{x}, \mathrm{y}) \& \exists \mathrm{z}[\mathrm{hammer}(\mathrm{z}) \& \operatorname{Instr}(\mathrm{e}, \mathrm{z})] \& \operatorname{INDIV}(\mathrm{e})]$

b. ombrellata $\lambda \mathrm{e}[\boldsymbol{H i t}(\mathrm{e}, \mathrm{x}, \mathrm{y}) \& \exists \mathrm{z}[\mathrm{umbrella}(\mathrm{z}) \& \operatorname{Instr}(\mathrm{e}, \mathrm{z})] \& \operatorname{INDIV}(\mathrm{e})]$

The question that arises is where does this specification comes into the derivational process. If the nominalized form is derived from an underlying (and virtual) verbal base, as it is assumed for ombrellata, then the specification must have entered the semantics of the virtual verb. This however would either require different verbalization rules or a specification of an unattested (virtual) form. Both options are not very attractive and might lead to unwelcome consequences for the whole system. To be clear, I do not deny that denominal verbs can be derived by a general rule and then instantiated according to specific contexts (see Clark \& Clark 1979), but this cannot be the case for unattested forms since they do not stand in any context. ${ }^{17}$

This means the only other option is that the direct derivation is more specified. Here again, it seems that we have two options: either we assume different specified derivation rules or a general rule and then specify the outcome in the context. The latter runs into a similar problem as before: if it is the context that finally decides on the specified meaning of the nominalization, it is hard to explain why we predominantly find certain patterns. On the other hand, different derivation rules would destroy the unity of the phenomenon (at least of the suffix). Therefore, I will present an alternative: I assume a general template that is sensitive to conceptual information of the base $N$. This conceptual information determines a certain specification and creates different particular templates. This means, I assume a general structure that is common to all templates and additional particular specifications that are determined by the conceptual semantics of the base. The relevant conceptual properties of the nominal base are represented as semantic features. The general form of the suffix is (62a) and (62b) in a simplified form where the predicate $P$ comprises the underlined information in (62a). So we can give the semantic representation for the template for the hit-reading, as in $(62 \mathrm{c})$ or simplified in $(62 \mathrm{~d})$ :
a. $-a t a$

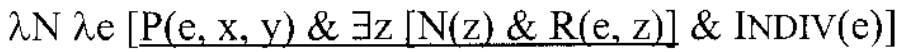
b. -ata
$\lambda N \lambda \mathrm{e}$
$\mathrm{P}(\mathrm{e}, \mathrm{x}, \mathrm{y} ; \mathrm{N})$
$\& \operatorname{INDIV}(\mathrm{e})]$
c. -atahit

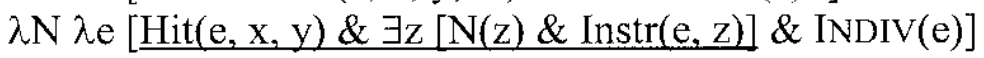
d. -atahit
$\lambda \mathrm{N} \lambda \mathrm{e}[$
Hit(e, $x, y$, with(N))
$\& \operatorname{INDIV}(\mathrm{e})]$

Thus we get several patterns that differ in the way the predicate $P$ is spelled out. The decisive factors are the thematic structure, the argument role of the base and the conceptual restriction on that argument (represented by selectional restrictions), as spelled out in (63)-(66) (in the simplified predicates $P$ for the longer information): ${ }^{18}$

$$
\begin{aligned}
& \text { (hit) } \mathrm{N}-a \text { ta: Event of hitting with } \mathrm{N} \text { or "hitting with } \mathrm{N} \text { " } \\
& \mathrm{P}=\operatorname{hit}(\mathrm{e}, \mathrm{x}, \mathrm{y}, \text { with } \mathrm{N}) \\
& -a t a: \lambda \mathrm{N} \lambda \mathrm{e}[\text { hit }(\mathrm{e}, \mathrm{x}, \mathrm{y}, \text { with } \mathrm{N}) \& \operatorname{INDIV}(\mathrm{e})] \\
& \mathrm{N}:+\operatorname{solid}+\operatorname{small}
\end{aligned}
$$

a. $\quad l i b r[+ \text { solid, }+ \text { small }]^{-a t a}$

$$
\begin{aligned}
& \lambda \mathrm{x}[\operatorname{book}(\mathrm{x})] \lambda \mathrm{N} \lambda \mathrm{e}\left[\mathrm{hit}\left(\mathrm{e}, \mathrm{x}, \mathrm{y}, \text { with } \mathrm{N}_{[+ \text {solid, }}+\text { small }\right]\right. \\
& \Rightarrow \lambda \mathrm{e}[\mathrm{hit}(\mathrm{e}, \mathrm{x}, \mathrm{y}, \text { with book }) \& \operatorname{end})] \\
&
\end{aligned}
$$

\footnotetext{
17 Another argument against a virtual verbal form is that once there is such a form it would allow for other derivations by other suffixes. However, this is not attested.

18 (65) and (66) pose an additional problem since the referential argument is not the event-argument, but the second argument of the predicate. For the time being, I do not have to offer any account for this.
} 


\section{6}

(act) N-ata: Event typically performed by $\mathrm{N}$ or "act as $\mathrm{N}$ "

$\mathrm{P}=\operatorname{act}(\mathrm{e}, \mathrm{x}$, as $\mathrm{N})$

-ata: $\lambda \mathrm{N} \lambda \mathrm{e}[\operatorname{act}(\mathrm{e}, \mathrm{x}$, as $\mathrm{N}) \& \operatorname{INDIV}(\mathrm{e})]$

$\mathrm{N}$ : +human

a. $\quad \operatorname{ragazz}[+ \text { human }]^{-a t a}$

$\lambda \mathrm{x}[\operatorname{child}(\mathrm{x})] \lambda \mathrm{N} \lambda \mathrm{e}\left[\operatorname{act}\left(\mathrm{e}, \mathrm{x}\right.\right.$, as $\left.\left.\left.\mathrm{N}_{[+ \text {human }}\right)\right) \& \operatorname{InDIV}(\mathrm{e})\right]$

$\Rightarrow \lambda \mathrm{e}[\operatorname{act}(\mathrm{e}, \mathrm{x}, \mathrm{as} \operatorname{child})) \& \operatorname{INDIV}(\mathrm{e})]$

(capacity) N-ata: Capacity that can be carried by/in $\mathrm{N}$

$\mathrm{P}=\operatorname{transp}(\mathrm{e}, \mathrm{x}, \mathrm{y}$, with $\mathrm{N})$

$-a t a: \lambda \mathrm{N} \lambda \mathrm{y}[\operatorname{transp}(\mathrm{e}, \mathrm{x}, \mathrm{y}$, with $\mathrm{N}) \& \operatorname{INDIV}(\mathrm{e})]$

$\mathrm{N}:+$ container

a. $\quad b o c c[+$ container $]-a t a$

$\lambda \mathrm{x}[$ mouth $(\mathrm{x})] \lambda \mathrm{N} \lambda \mathrm{y}\left[\operatorname{transp}\left(\mathrm{e}, \mathrm{x}, \mathrm{y}\right.\right.$, in $\left.\left.\mathrm{N}_{[+ \text {container }}\right) \& \operatorname{INDIV}(\mathrm{e})\right]$

$\Rightarrow \lambda y[\operatorname{transp}(e, x, y$, in mouth) $\& \operatorname{InDIV}(\mathrm{e})]$

(meal) N-ata. Meal prepared on the base of $\mathrm{N}$

$\mathrm{P}=\operatorname{prep}(\mathrm{e}, \mathrm{x}, \mathrm{y}$, with $\mathrm{N})$

$-a t a: \lambda \mathrm{N} \lambda \mathrm{y}[\operatorname{prep}(\mathrm{e}, \mathrm{x}, \mathrm{y}$, with $\mathrm{N}) \& \operatorname{INDIV}(\mathrm{e})]$

$\mathrm{N}:+$ eatable

a. fung $[+ \text { eatable }]^{-a t a}$

$\lambda x[$ mushroom $(x)] \lambda N \lambda y\left[p r e p\left(e, x, y\right.\right.$, with $\left.\left.\mathrm{N}_{[+ \text {eatable }}\right) \& \operatorname{INDIV}(e)\right]$

$\Rightarrow \lambda y[$ prep(e, $x, y$, with mushroom $) \& \operatorname{INDIV}(e)]$

Italian nominalizations in -ata are formed from verbal as well as from nominal bases. Derivations from verbal bases refer to a single event denoted by the base. Derivations from a nominal base $N$ denote events or results corresponding to a limited number of patterns, such as a hit by $N$, a characteristic action of $N$, a period of $N$, a quantity that is contained in $N$, etc. The particular reference is determined by the lexical semantics of the base and the suffix, and by the conceptual structure of the base. The paper has argued that the function of the suffix operates on the lexical meaning of the base, but the composition of the lexical meaning of the base with the lexical meaning of the suffix is restricted by the conceptual properties of the base. In particular, the paper has addressed the following issues:

- The suffix - ata very productively forms nominalizations from verbal and from nominal bases.

- The suffix has a common function:

- categorial function: nouns in the feminine gender

- describing an individualized event or instance of an event

- describing events in which the base is pragmatically salient

- The notion of "pragmatically salient" can be spelled out in certain patterns for denominal derivations.

- These patterns are generally found in lexicalized forms. But they are also prominent patterns for spontaneous derivations.

- The choice of such a pattern depends among other factors on the conceptual restrictions of the objects associated with the base.

- The conceptual restrictions of objects are encoded in semantic features associated with the base.

- A more complex conceptual structure, interaction with other items or relation between different items must be investigated. 


\section{References}

Alexander, Luther H. [1912] (1966): Participial Substantives of the -ata Type in the Romance Languages with Special Reference to French. Reprint [of the edition] New York 1912. New York: Ams Pr.

Appel, Ernst (1883): De genere neutro intereunte in lingua latina. Dissertation Erlangen.

Aronoff, Mark (1979): Word Formation in Generative Grammar. Cambridge/Mass.: MIT Press.

Bierwisch, Manfred (1989): Event-Nominalizations. Proposals and Problems. In: W. Motsch (ed.): Wortstruktur und Satzstruktur. Berlin, 1-73.

Clark, Eve \& Clark, Herbert (1979): When Nouns Surface as Verbs. Language 55, 767-811.

Collin, Carl S. (1914): Zur Geschichte der Nomina actionis im Romanischen. Archiv für lateinische Lexikographie und Grammatik 13, 453-473.

Collin, Carl S. (1918): Étude sur le dévelopement de sens du suffixe -ata (it. -ata, prov., esp., port. -ata, fr. -ée, ade) dans les langues romanes, spécialement au point de vue du français. Lund : Lindstedts.

Ehrich, Veronika (1991): Nominalisierungen. In: A. von Stechow \& D. Wunderlich (eds.). Semantik. Ein internationales Handbuch der zeitgenössischen Forschung. Berlin: de Gruyter, 441-458.

Ehrich, Veronika \& Rapp, Irene (2000): Sortale Bedeutung und Argumentstruktur: ung-Nominalisierungen im Deutschen. Zeitschrift für Sprachwissenschaft 19, 245-303.

Grimshaw, Jane (1990): Argument Structure. Cambridge/Mass.: MIT Press.

Ippolito, Michaela (1999): On the Past Participle Morphology in Italian. In: MIT Working Papers in Linguistics 33, $111-137$.

Jackendoff, Ray (1990): Semantic Structures. Cambridge/Mass.: MIT-Press.

Jackendoff, Ray (1996): Semantics and Cognition. In: S. Lappin (ed.): The Handbook of Contemporary Semantic Theory. Oxford: Blackwell, 539-559.

Jackendoff, Ray (1997): The Architecture of the Language Faculty. Cambridge/ Mass.: MIT Press.

von Heusinger, Klaus (2002): Italian Nominalization of -ata: Derivation and the Structure of the Lexicon. Arbeitspapier 109. Fachbereich Sprachwissenschaft, Universität Konstanz.

Kaufmann, Ingrid (1995): Konzeptuelle Grundlagen semantischer Dekompositionsstrukturen. Die Kombinatorik lokaler Verben und prädikativer Komplemente. Tübingen: Niemeyer.

Lindquist, Axel (1936) Studien über Wortbildung und Wortwahl im Althochdeutschen. PBB [= Beiträge zur Geschichte und Sprache der deutschen Literatur] 60, 1-132.

Mayo, Bruce \& Schepping, Marie-Therese \& Schwarze, Christoph \& Zaffanella, Angela (1995): Semantics in the Derivational Morphology of Italian: Implications for the Structure of the Lexicon. Linguistics 33, 883938.

Meyer-Lübke, Wilhelm (1890): Italienische Grammatik. Leipzig: Reisland.

Pustejovsky, James (1991): The Syntax of Event Structure. Cognition 41, 47-81.

Ruh, Kurt 1956. Bonaventura deutsch. Ein Beitrag zur deutschen Franziskaner-Mystik u. -Scholastik. Bern: Francke.

Sabatini, Francesco \& Coletti, Vittorio (1997): DISC: Dizionario Italiano Sabatini Coletti. Ed. in CD-ROM, versione 1.1. Firenze: Giunti Multimedia.

Samek-Lodovici, Vieri (1997): A Unified Analysis of Noun- and Verb-based Italian Nominalization in -ata. Arbeitspapier 80. Fachgruppe Sprachwissenschaft. Universität Konstanz.

Samek-Lodovici, Vieri (1999): The Internal Structure of Arguments. Evidence from Italian Nominalizationbased Complex Predicates. Arbeitspapier 102. Fachgruppe Sprachwissenschaft. Universität Konstanz.

Scalise, Sergio [1986] (1990): Morfologia e lessico. Una prospettiva generativista. Bologna: Il Mulino.

Schwarze, Christoph [1988] (1995): Grammatik der italienischen Sprache. 2. verb. Aufl. Tübingen: Niemeyer.

Schwarze, Christoph (2001): Aspetti semantici della formazione delle parole. Arbeitspapier 106. Fachbereich Sprachwissenschaft. Universität Konstanz.

Stiebels, Barbara (1996): Lexikalische Argumente und Adjunkte. Zum semantischen Beitrag von verbalen Präfixen und Partikeln. Berlin: Akademie Verlag (=Studia grammatica 39).

Wunderlich, Dieter (1997): CAUSE and the Structure of Verbs. In: Linguistic Inquiry 28. 27-68. 